\title{
Antibacterial and antifungal prospective of cypress vine (Ipomoea quamoclit Linn)
}

Kushnood Ur Rehman ${ }^{1}$, Muhammad Hamayun ${ }^{2}$, Gulzad Ahmad ${ }^{1}$, Wali Samad Khan ${ }^{2}$, Sayyar Muhammad ${ }^{3}$, Rani Gul ${ }^{4}$ and Tabassum Yaseen ${ }^{5 *}$

1. Department of Botany, Islamia Collage Peshawar-Pakistan

2. Department of Botany, Abdul Wali Khan University Mardan, 23200-Pakistan

3. Department of Chemistry, Islamia Collage Peshawar-Pakistan

4. Department of Agriculture, Bacha Khan University Charsadda Khyber Pakhtunkhwa-Pakistan

5. Department of Botany, Bacha Khan University Charsadda Khyber Pakhtunkhwa-Pakistan

*Corresponding author's email: tabassumyaseen@bkuc.edu.pk

Citation

Kushnood Ur Rehman, Muhammad Hamayun, Gulzad Ahmad, Wali Samad Khan, Sayyar Muhammad, Rani Gul and Tabassum Yaseen. Antibacterial and antifungal prospective of cypress vine (Ipomoea quamoclit Linn). Pure and Applied Biology. Vol. 9, Issue 1, pp464-470. http://dx.doi.org/10.19045/bspab.2020.90051

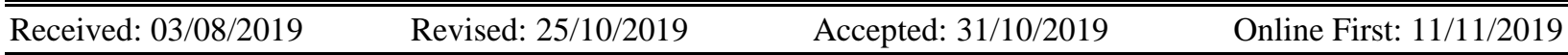

\section{Abstract}

The study established out to find the anti-fungal and anti-bacterial action of Ipomoea quamoclit. We focus on the study to find fractions, which are active against bacterial and fungal species. The fractions aqueous, chloroform, n-hexane, methanolic extract and ethyl acetate was obtained and were tested against the selected four fungal and four bacterial species which are very common in different hospitals of Khyber Pakhtunkhwa. The n-hexane fractions inhibit the growth of bacterial strains (46-48\%) which was the highest inhibition zone and the lowest activity shown by crude methanolic extracts (38-44\%) against all the selected bacterial strains. However, in ant-fungal activity, the highest activity shown by crude methanolic extracts (35-65\%) against the four selected fungal species and lowest activity displayed by the aqueous fractions. The other fractions also shown some moderate activity but were significant.

Keywords: Antibacterial; Antifungal; Cypress vine (Ipomoea quamoclit Linn); Inhibition

\section{Introduction}

From the initiation of this world, plants have a prominent role in the civilization of human beings. Some use for ornamental purpose while other for medicinal purpose. In such medicinal plants, Ipomoea quamoclit is a native species of America and spread throughout the Europe in 1500s. In both areas, it is studying for medical purposes. The species is reported from some regions of India. From some new reports, it was clear that it is also an ornamental species and people growing it in their homes and gardens. I. quamoclit also called morning glory and member of family Convulvolaceae. The climber flowers of the plant form an attractive and heart catching property in horticulture areas. At lower latitude across the world it is common and also touching the Ontario of Canada [1-3].

From many decade plants are either used directly as a traditional medicine or an alternative medicine against several diseases caused by pathogens $[4,5]$. Such knowledge spread with the help of conferences or writings across the world [4]. In different countries different traditional centers were open which based on plants like in china, 
Chinese medicines of china, Siddha, Unani medicines India and Unani dawakhanas in Pakistan [6]. A surveyed was carried out by World Health Organization that about $80 \%$ people across the world depended upon medicinal $[5,7]$. The plant medicines are very prominent because they possess either less or no side effect and very active against pathogens [8]. The bioactive substances such as flavonoids, alkaloids, tannins, glycosides, protein, amino acids, phenols and many other secondary metabolites [9]. Many readings were also conducted to find such biologically active substances in medicinal plants which play a very crucial role against disease causing agents but still many plants and their constituents were not known up to now [10]. Therefor different researchers are busy in their findings. In such regards the same study was also carried out to find the antifungal and antibacterial activity of Ipomoea quamoclit Linn (Cypress vine).

\section{Material and methods}

\section{Collection and processing of plant specimen}

Different areas of the Khyber Pakhtunkhwa were visited for the collection of Ipomoea quamoclit Linn plant. The collected plants were washed and dried in shadow followed by oven drying in the oven. The completely drying plants were powdered with the help of grinder. Then the powder stored at cool place before extraction.

\section{Preparation of extraction and fractions}

Cold maceration method was used for the extraction of the active metabolites. One and half of the powdered plant material was dipped in two later of ethanol and incubated for 5 days at $40^{\circ} \mathrm{C}$. The material filtered thrice and a clear filtrate was obtained. The filtrate was subjected for evaporation via rotatory evaporator at $40^{\circ} \mathrm{c}$. The obtained extract was dried and then dissolved in $100 \mathrm{ml}$ distilled water. The solution was the fractionate by using different organic solvents including ethanol, chloroform, n- hexane, methanol and ethyl acetate by using separating funnel. All the fraction thus obtained were concentrated by rotatory evaporator and designate for that solvent fraction.

\section{Media preparation}

Agar well diffusion method was used during antibacterial activity. One liter distilled water was to liquefy $25 \mathrm{~g}$ of Luria Both, $\mathrm{PH}$ of Miller powder was put at 7.0. The media put in autoclave in $250 \mathrm{ml}$ flask. The selected four bacterial stains were introduced into the flask and kept overnight at $150 \mathrm{RPM}$ at $37^{\circ} \mathrm{C}$. After that agar converted into solid form and by using sterilized borer five holes were tunneled. The inoculum was introduced into the tunneled. The bacterial and fungal species were selected due to their frequent occurrence in local hospitals of Khyber Pakhtunkhwa (KPK) and also showing resistance to different drugs.

\section{Test for bacterial strains}

Among the four selected bacterial strains three were gram positive and one strain is gram negative i.e MRSA (Methicillin resistance staphylococcus aurous), streptococcus mutans and staphylococcus aurous. And the gram negative is Serratia marcescens.

\section{Measurement of zones of inhibition}

Dimethyl sulfoxide $20 \mathrm{mg} / \mathrm{ml}$ was used as a negative control in which the extracts were dissolved. While the Cefotaxime (standard antibiotics) was used as a positive controller. The plant fraction about $75 \mu \mathrm{l}$ were introduced into the wells of petri dish and that petri dishes were positioned in the incubator at $37^{\circ} \mathrm{c}$ for twenty four (24) hours. When the incubation period was completed then the diameter of each transparent zone was measured. The experiment was repeated again and again to calculate the standard data. Test for fungal strains

During antifungal activity the four fungal strains were selected i.e Fusarium oxysporum, Aspergillus flavous, 
polyspondylium pallidum, and Alternaria alternate.

\section{Results and discussion}

The research study conducted to evaluate the anti-fungal and anti-bacterial potential of the cypress vine plant (Ipomoea quamoclit Linn.) plant. The results revealed that this plant is a very effective source for the inhibition of the growth of the tested species of both fungi and bacteria. The plant can be investigated for active metabolites to evolve the anti-bacterial and anti-fungal drugs through biochemical and biophysical essays.

\section{Antibacterial activities of Ipomoea quamoclit Linn}

In the current research work five fractions of I. quamoclit Linn extracts were used to know their potential use against the selected bacterial strains that are Staphylococcus aureus, Streptococcus mutans and Methicillin-resistant Staphylococcus aureus (MRSA) and Serratia marcescens. These species were selected for the current experiments on the basis of their frequent pathological reports from hospitals of Khyber Pakhtunkhwa. Results of the anti-fungal activity as shown in (Table 1 and Fig.1) showed that all the fractions were active against the selected bacterial strains. The growth of Methicillin-resistant Staphylococcus aureus (MRSA), Streptococcus mutans, Staphylococcus aureus and Serratia marcescens was inhibited by the crude methanolic extract with $10.0 \mathrm{~mm}, 12.0 \mathrm{~mm}, 09.0 \mathrm{~mm}$ and $11.0 \mathrm{~mm}$ zones of inhibition respectively. The $n$. hexane extracted fractions inhibited the growth of Staphylococcus aureus, Streptococcus mutans, Serratia marcescens and Methicillin-resistant Staphylococcus aureus (MRSA) with $12.0 \mathrm{~mm}, 13.0 \mathrm{~mm}$, $14.0 \mathrm{~mm}$ and $10.0 \mathrm{~mm}$ zones of inhibition respectively. The chloroform fractions were produced $11.0 \mathrm{~mm}, 14.0 \mathrm{~mm}, 07.0 \mathrm{~mm}$ and $14.0 \mathrm{~mm}$ zones of inhibition against Staphylococcus aureus, Streptococcus mutans, Serratia marcescens and Methicillin-resistant Staphylococcus aureus (MRSA) respectively. The ethyl acetate fraction was most active against Streptococcus mutans $\quad(\mathrm{ZOI}=10.0 \mathrm{~mm})$ followed by Methicillin-resistant Staphylococcus aureus (ZOI $=09.0 \mathrm{~mm})$, Staphylococcus aureus $(\mathrm{ZOI}=08.0 \mathrm{~mm})$ and Serratia marcescens (ZOI $=08.0 \mathrm{~mm})$. The aqueous extracted fraction inhibited the growth of tested bactrail strains in the order of Methicillin-resistant Staphylococcus aureus $\quad(\mathrm{ZOI}=08.0 \mathrm{~mm}), \quad$ Staphylococcus aureus $(\mathrm{ZOI}=05.0 \mathrm{~mm})$, Serratia marcescens $(\mathrm{ZOI}=05.0 \mathrm{~mm})$ and Streptococcus mutans $(\mathrm{ZOI}=04.0 \mathrm{~mm}) \quad$ respectively. Globally several hundred genera of medicinal plants are used as the main sources of anti-bacterial drugs [11, 12]. According to [13] in the previous century most of the faculties in the medicine sector switched their concern from natural to synthetic drugs. But for the last few decades this trend is shifting in the reverse direction $[14,15]$. In a survey $25 \%$ of the drug prescriptions in 35 countries are plants derived in non-modified or little modified [16-19]. 
Table 1. Antibacterial activity of the crude extracts of Ipomoea quamoclit

\begin{tabular}{|c|c|c|c|c|c|c|}
\hline \multicolumn{7}{|c|}{ Anova: Two-Factor Antibacterial } \\
\hline Summary & Count & Sum & Average & \multicolumn{3}{|c|}{ Variance } \\
\hline MRSA & 6 & 87 & 14.5 & \multicolumn{3}{|c|}{70.3} \\
\hline S. marcescens & 6 & 76 & 12.66667 & \multicolumn{3}{|c|}{69.46667} \\
\hline S. mutans & 6 & 82 & 13.66667 & \multicolumn{3}{|c|}{82.66667} \\
\hline S. aureus & 6 & 92 & 15.33333 & \multicolumn{3}{|c|}{126.6667} \\
\hline Standard & 4 & 123 & 30.75 & \multicolumn{3}{|c|}{21.58333} \\
\hline Cr. Met. Ext & 4 & 54 & 13.5 & \multicolumn{3}{|c|}{4.333333} \\
\hline n- hexane & 4 & 41 & 10.25 & \multicolumn{3}{|c|}{2.916667} \\
\hline $\mathrm{CHCl} 3$ & 4 & 39 & 9.75 & \multicolumn{3}{|c|}{4.916667} \\
\hline EtOAc & 4 & 63 & 15.75 & \multicolumn{3}{|c|}{4.916667} \\
\hline Aqueous & 4 & 17 & 4.25 & \multicolumn{3}{|c|}{2.916667} \\
\hline \multicolumn{7}{|l|}{ ANOVA } \\
\hline Source of variation & SS & df & MS & $\mathbf{F}$ & P-value & F crit \\
\hline Rows & 23.45833 & 3 & 7.819444 & 1.15796 & 0.358338 & 3.287382 \\
\hline Columns & 1644.208 & 5 & 328.8417 & 48.69724 & $9.6 \mathrm{E}-09$ & 2.901295 \\
\hline Error & 101.2917 & 15 & 6.752778 & - & - & - \\
\hline Total & 1768.958 & 23 & & - & - & - \\
\hline
\end{tabular}

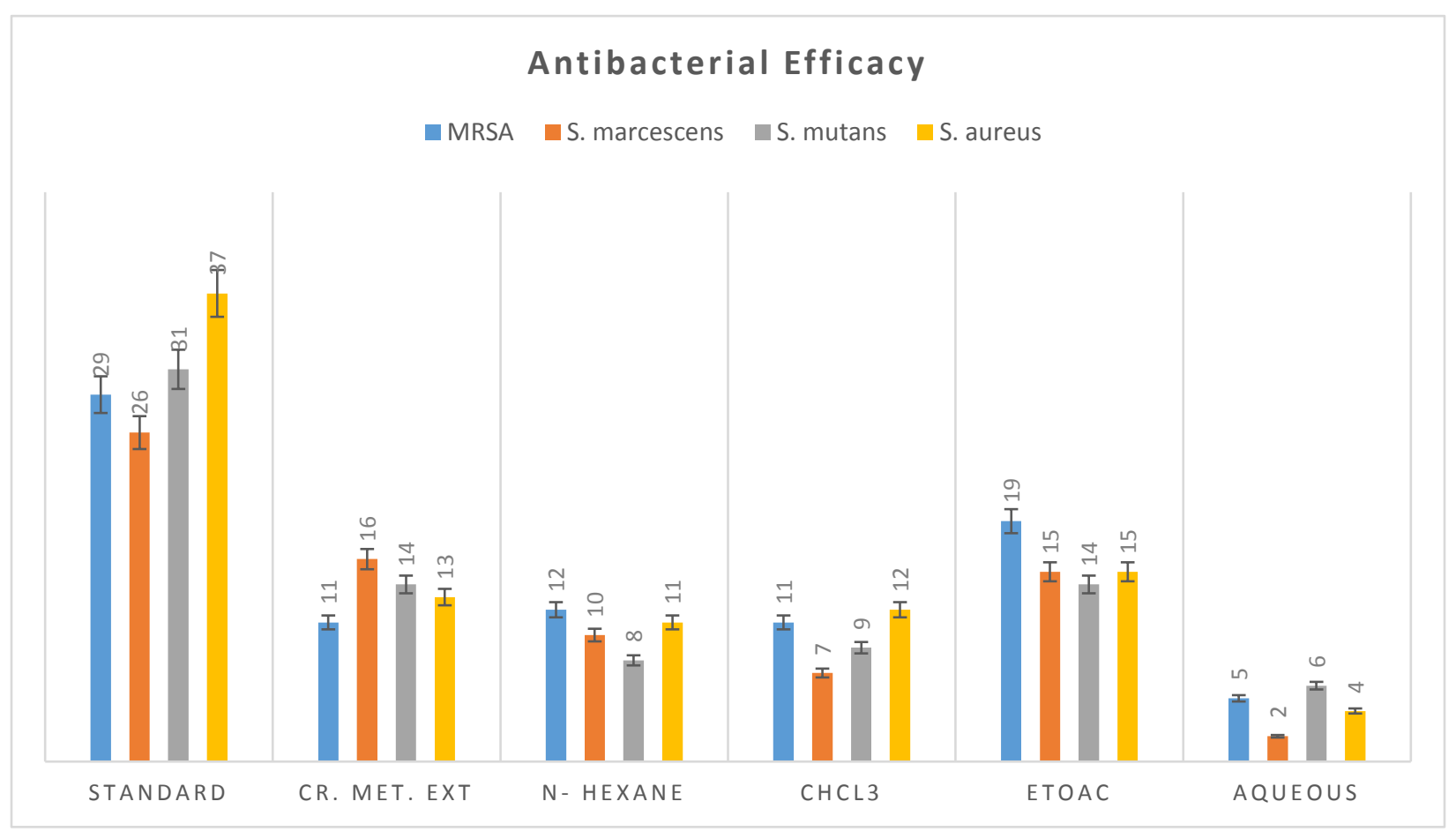

Figure 1. Antibacterial efficacy of Ipomoea quamoclit Linn

Antifungal activities of Ipomoea quamoclit Linn

Effects of the anti-fungal activity as shown in (Table $2 \&$ Fig. 2) showed that the n-hexane extracted sample inhibited the growth of
Fusarium oxysporum completely. Chloroform and Ethyl acetate inhibited the growth of Polysphondylium pallidum. While the aqueous extract showed significant activity against Aspergillus flavus and 
Alternaria alternate. Crude methanolic extract showed good results against Polysphondylium pallidum. Trend in results revealed that Fusarium oxysporum is comparatively more sensible to the n-hexane extracts, Polysphondylium pallidum to chloroform and Ethyl acetate extracts while Aspergillus flavus and Alternaria alternate to the aqueous extracts of plants. The usage of medicinal plants as anti-fungals is quite old practice performed by human beings. These result in the production of important compounds that are used to develop drugs against fungal pathogens. One of the positive aspects of these drugs is this that these drugs have very little adverse/side effects on the human health $[5,20]$. The demand for the development anti-fungal drugs has enormously increased as it is established that among others fungal pathogens are causing serious losses in the quantity, quality, shelf life and mortality of the crop plants [21]. In regard to humans, fungi as the cause of diseases offer a new aspect of human pathology [22]. In this regard medicinal plants are proved to be the sources for the discovery of new drugs $[23,24]$. In the developing countries, which face the problems of the quantity and quality of modern drugs, medicinal plants derived compounds have recently gained much importance and their old traditional uses are valued much more nowadays [25]. The current study revealed that antifungal activity of the wild plants proved to be much more significant and can be a very suitable substitute of the modern medicines. Similar findings have been reported by [26], for the fungus Alternaria alternate. Similarly [6] publicized that the crude methanolic extract of the medicinal plants showed maximum anti-fungal properties which is in agreement with our work. Similar results with other medicinal plants were reported by $[27,28]$.

Table 2. Two factor ANOVA of antifungal

\begin{tabular}{|c|c|c|c|c|c|c|}
\hline \multicolumn{7}{|c|}{ Anova: Two-Factor antifungal } \\
\hline Summary & Count & Sum & Average & \multicolumn{3}{|c|}{ Variance } \\
\hline A.flavus & 6 & 220 & 36.66667 & \multicolumn{3}{|c|}{1129.067} \\
\hline A. alternate & 6 & 209 & 34.83333 & \multicolumn{3}{|c|}{1286.167} \\
\hline F. oxysporum & 6 & 234 & 39 & \multicolumn{3}{|c|}{1033.2} \\
\hline P. pallidum & 6 & 243 & 40.5 & \multicolumn{3}{|c|}{908.3} \\
\hline Standard & 4 & 400 & 100 & \multicolumn{3}{|c|}{0} \\
\hline Cr. Met. Ext & 4 & 141 & 35.25 & \multicolumn{3}{|c|}{9.583333} \\
\hline n- hexane & 4 & 76 & 19 & \multicolumn{3}{|c|}{88.66667} \\
\hline $\mathrm{CHCl3}$ & 4 & 88 & 22 & \multicolumn{3}{|c|}{60} \\
\hline EtOAc & 4 & 158 & 39.5 & \multicolumn{3}{|c|}{25} \\
\hline Aqueous & 4 & 43 & 10.75 & \multicolumn{3}{|c|}{164.9167} \\
\hline \multicolumn{7}{|l|}{ ANOVA } \\
\hline Source of variation & SS & df & MS & $\mathbf{F}$ & P-value & F crit \\
\hline Rows & 112.8333 & 3 & 37.61111 & 0.605546 & 0.621516 & 3.287382 \\
\hline Columns & 20852 & 5 & 4170.4 & 67.14419 & $9.94 \mathrm{E}-10$ & 2.901295 \\
\hline Error & 931.6667 & 15 & 62.11111 & - & - & - \\
\hline Total & 21896.5 & 23 & & - & - & - \\
\hline
\end{tabular}




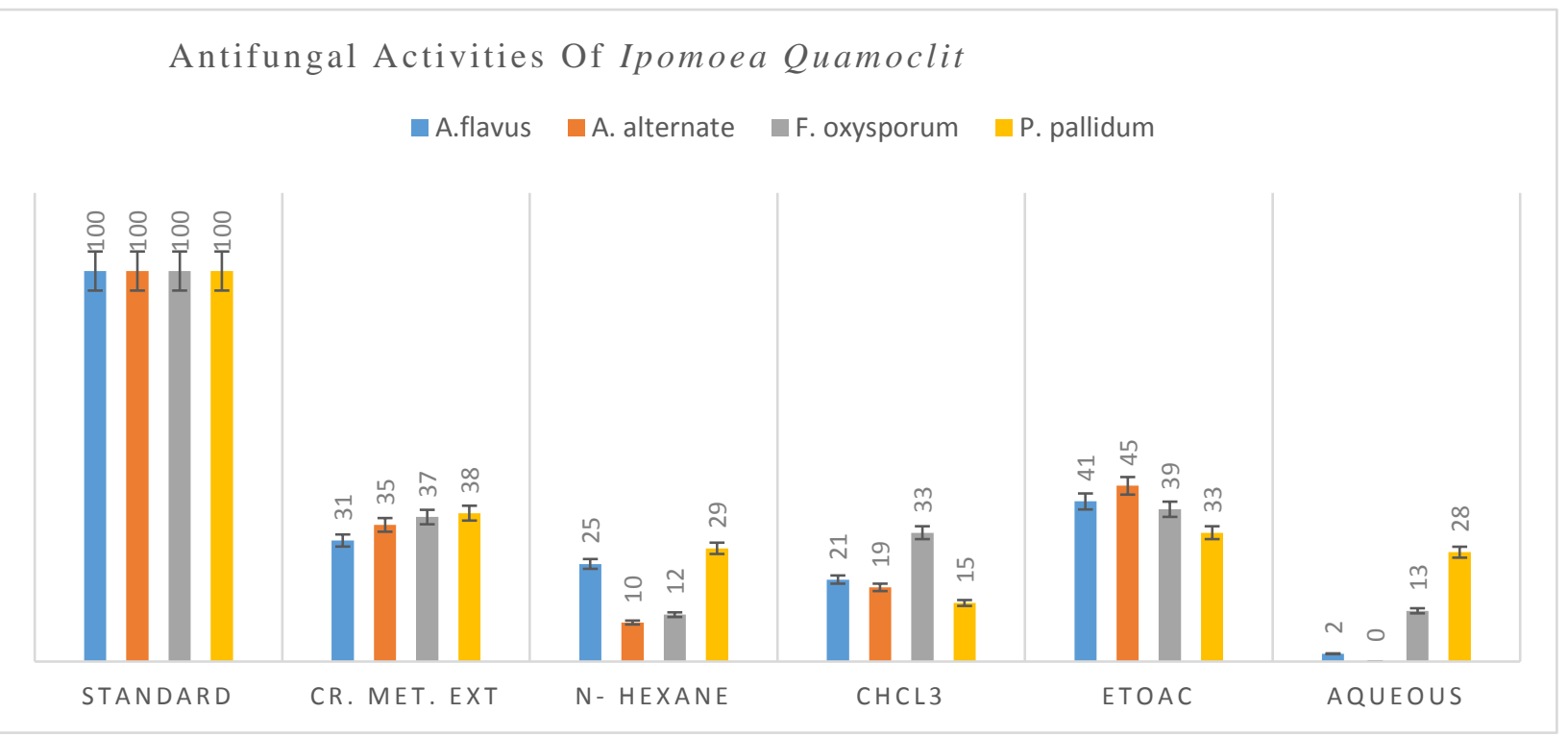

Figure 2. Antifungal efficacy

\section{Conclusion}

It is evident from the results of anti-bacterial and anti-fungal activities that the selected plant i.e. Ipomoea quamoclit Linn possessed very significant properties. The crude methanolic and ethanolic.

\section{Authors' contributions}

Conceived and designed the experiments: KU Rehman' G Ahmad, WS Khan \& S Muhammad, Performed the experiments: G Ahmad, WS Khan \& S Muhammad, Analyzed the data: KU Rehman \& M Hamayun, Contributed materials/ analysis/ tools: R Gul \& T Yaseen, Wrote the paper: KU Rehman.

\section{References}

1. Austin DF (2013). The origin of quamoclit (Ipomoea quamoclit, Convolvulaceae): A Review. Economic Bot 67(1): 63-79.

2. Rebman JP \& Simpson MG (2006). Checklist of the vascular plants of San Diego County. San Diego Natural History Museum San Diego, CA.

3. Tabassum N \& Vidyasagar G (2013). Antifungal investigations on plant essential oils. A review," Inter $J$ of Pharmacy and Pharm Sci 5(2): 19-28.

4. YI TS, Morrell PL, PEI SJ \& He SA (2015). Major introduced economic plants, Plants of China: A Companion to the Flora of China pp 357.
5. Paul D \& Sinha SN (2016). An update on biological activities of medicinal plant Ipomoea quamoclit L. Trop Plant Res 3(186): e190.

6. Ho KL, Chung WE, Choong KE, Cheah YL, Phua EY \& Srinivasan R (2015). Antiproliferative activity and preliminary phytochemical screening of Ipomoea quamoclit leaf extracts. Res J Med Plant 9: 127-134.

7. Singh N, Sharma JK \& Santal AR (2016). Biotechnological Approaches to Remediate Soil and Water Using PlantMicrobe Interactions in Phytoremediation: Springer, pp 131-152.

8. Cragg GM \& Newman DJ (2013). Natural products: a continuing source of novel drug leads. Biochimica et Biophysica Acta (BBA)-General Subjects 1830(6): 36703695.

9. Londhe D, Neel R \& Bhuktar A (2017). Ethno-medicinal uses of some species of genus Ipomoea L. from Maharashtra state. Int J Appl Res 3(10): 82-84.

10. Zhang LX, Bai YP, Song PH, You LP \& Yang DQ (2009). Effect of Chinese herbal medicine combined with acitretin capsule in treating psoriasis of blood-heat syndrome type. Chinese J of Integr Med 15(2): 141-144. 
11. Moin S, Shibu BS, Wesley PS \& Devi BC (2012). In vitro Screening of Antibacterial Protein Activity from Medicinal and Economically Important Plants Seed. Drug Invention Today 4(10).

12. Rahmatullah M, Ferdausi D, Mollik MAH, Azam MNK, Rahman M \& Jahan (2009). Ethnomedicinal survey of Bheramara area in Kushtia district, Bangladesh," American Eurasian J of Sustainable Agric 3(3): 534541.

13. Uddin MJ, Patari P, Nag SK \& Sil SK (2018). A comparative study on ethno medicinal and nutraceutical potentials of the leaves of three species of genus Ipomea from Tripura, NE-India. $J$ of Pharmacognosy and Phytochem 7(1): 2073-2082.

14. Basavaraju R, Raj JV \& Bhiravamurthy P (2009). Medicinal plant resources of Puttaparthi Mandal: Taxonomic overview and need for conservation. Ethnobot Leaflets 2009(11): 6.

15. Cruz-Morales S, Castañeda-Gómez J, Figueroa-González G, Mendoza-García $\mathrm{AD}$, Lorence A \& Pereda-Miranda $\mathrm{R}$ (2012). Mammalian multidrug resistance lipopentasaccharide inhibitors from Ipomoea alba seeds. J of Nat Products 75(9): 1603-1611, 2012.

16. Kuiper HA, Kleter GA, Noteborn HP \& Kok EJ (2001). Assessment of the food safety issues related to genetically modified foods. The Plant J 27(6): 503528.

17. Farnsworth NR, Akerele O, Bingel AS, Soejarto DD \& Guo Z (1985). Medicinal plants in therapy. Bulletin of the World Health Org 63(6): 965.

18. Farnsworth NR \& Soejarto D (1991). Global importance of medicinal plants. The Conserv of Med Plants 26: 25-51.
19. Rehman K et al. (2019). Evaluation of the antibacterial and antifungal potential of spider saxifrage plant (Saxifraga flagellaris Willd.). Pure and Appl Biol 8(2): 1163-1171.

20. Shamshad, Khan S, Waqas M, Ahmad N, Ur-Rehman K \& Khan K (2015). Removal and bioaccumulation of heavy metals from aqueous solutions using freshwater algae. Water Sci and Technol 71(1): 38-44.

21. Défago G et al. (2001). Towards the biocontrol of bindweeds with a mycoherbicide. Bio Control 46(2): 157173.

22. de Carvalho F, Queiroz J \& de Toledo R (2011). Efficacy of amicarbazone herbicide in controlling morningglories in sugar cane (Saccharum spp.) crop. Revista Brasileira de Herbicidas 10(3): 183-189.

23. Haque SM \& Ghosh B (2013). In vitro completion of sexual life cycle: production of R1 plants of Ipomoea quamoclit L. Propagation of Ornamental Plants 13(1): 19-24.

24. Leistner E \& Steiner U (2009). Fungal origin of ergoline alkaloids present in dicotyledonous plants (Convolvulaceae). Physiol and Genetics: Springer 197-208.

25. Sahu PK \& Gupta S (2014). Medicinal plants of Morning glory: Convolvulaceae Juss. of Central India (Madhya Pradesh and Chhattishgarh). Biolife 2(2): 463-469.

26. Kumar N (2014). Common medicinal plants available at Joginder Nagar, District Mandi (HP), India. Res in Pharm.

27. Reddy R \& Kumar S (2015). Anti-diabetic activity of Ipomoea quamoclit in Streptozotocin Induced diabetic rats. $J$ of Pharmacognosy and Phytochem 4(1).

28. Yadav R \& Agarwala M (2011). Phytochemical analysis of some medicinal plants. $J$ of phytol. 